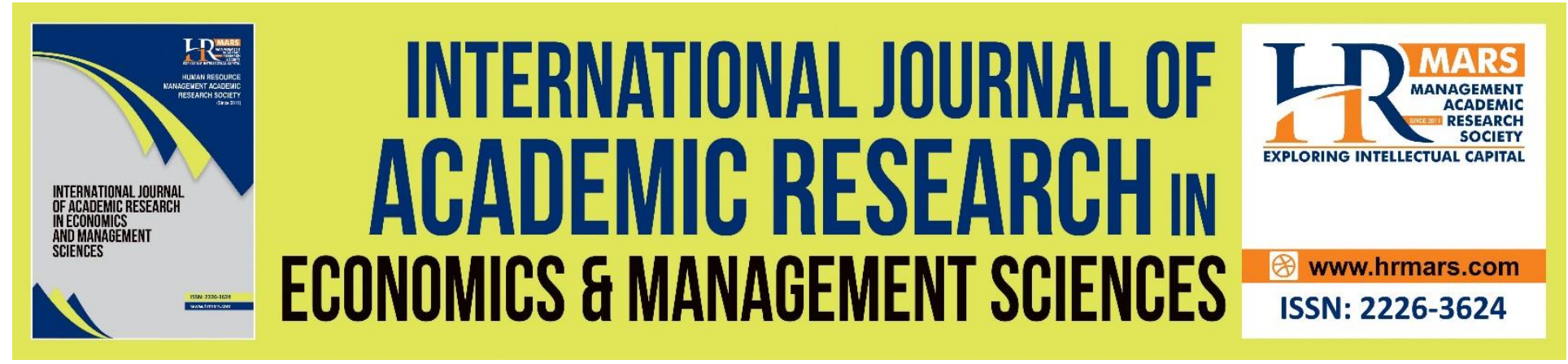

\title{
The Impact of Remittance on Economic Growth in Low and Middle Income Countries
}

Zakaria Lacheheb, Normaz Wana Ismail

To Link this Article: http://dx.doi.org/10.6007/IJAREMS/v9-i2/7503

DOI: 10.6007/IJAREMS/v9-i2/7503

Received: 23 March 2020, Revised: 26 April 2020, Accepted: 20 May 2020

Published Online: 24 June 2019

In-Text Citation: (Lacheheb, \& Ismail, 2020)

To Cite this Article: Lacheheb, Z., \& Ismail, N. W. (2020). The Impact of Remittance on Economic Growth in Low and Middle income Countries. International Journal of Academic Research in Economics \& Management Sciences. 9(2), 61-70.

Copyright: (C) 2020 The Author(s)

Published by Human Resource Management Academic Research Society (www.hrmars.com)

This article is published under the Creative Commons Attribution (CC BY 4.0) license. Anyone may reproduce, distribute, translate and create derivative works of this article (for both commercial and non-commercial purposes), subject to full attribution to the original publication and authors. The full terms of this license may be seen at: http://creativecommons.org/licences/by/4.0/legalcode

Vol. 9, No. 2, 2020, Pg. 61 - 70

http://hrmars.com/index.php/pages/detail/IJAREMS

JOURNAL HOMEPAGE

Full Terms \& Conditions of access and use can be found at http://hrmars.com/index.php/pages/detail/publication-ethics 


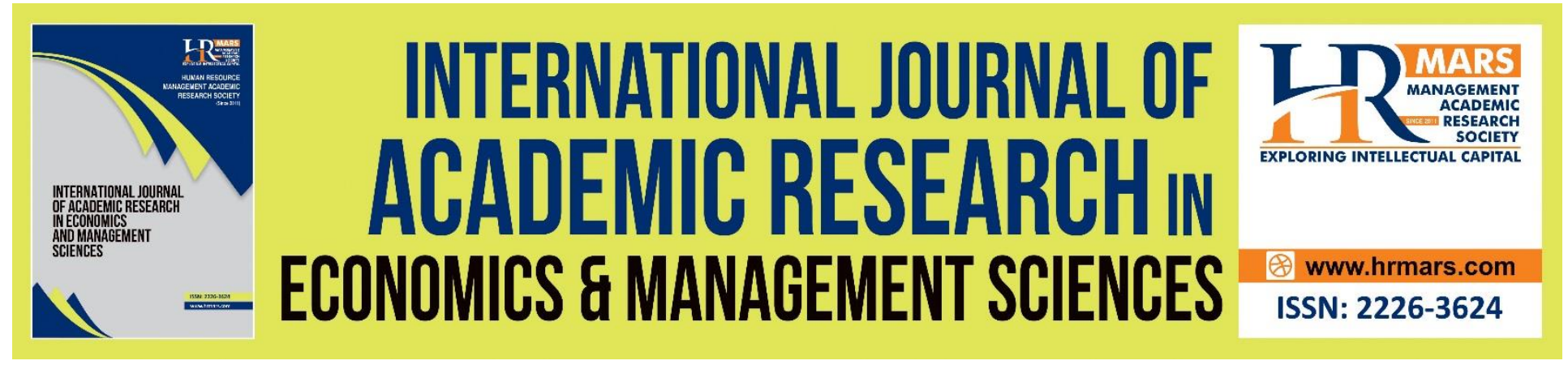

\title{
The Impact of Remittance on Economic Growth in Low and Middle Income Countries
}

\author{
Zakaria Lacheheb, Normaz Wana Ismail \\ School Business and Economics, Universiti Putra Malaysia, 43400 Serdang, Selangor, Malaysia \\ Email: zakitchy@gmail.com, nwi@upm.edu.my
}

\begin{abstract}
This study investigates the relationship between remittance and economic growth in a panel of 93 low and middle-income countries using annual data from 2009 to 2017. The estimated model using system GMM (SYS-GMM) revealed that remittance has a significant negative impact on growth after removing outliers. However, the result before outliers was indicating a negative but nonsignificant relationship between remittance and growth. The results confirm that remittance flow leads to deteriorating economic growth in the receiving countries. Therefore, these findings suggest that countries with a big size of remittance are predicted to be associated with a low level of growth which indicates a remittance curse effect on the countries' level of economic growth.
\end{abstract}

Keywords: Remittance, Economic Growth, Curse, Blessing, SYS-GMM.

\section{Introduction}

Remittance plays an important role on economic development globally, such as the impact of remittances on poverty alleviation, education, labor supply, and economic growth (Adams \& Page, 2005; Giuliano \& Arranz, 2005; Edwards \& Ureta, 2003; Fajnzylber \& Lopez, 2008). Remittance is a lifeline for millions of recipients that are mostly living in poverty. It can lead to poverty alleviation in emigrants' home countries (Migration Development brief, 2017). The small amounts of $\$ 200$ or $\$ 300$ that each migrant sends home make up about $60 \%$ of their families' household income, and recipients spend about $10 \%$ and $15 \%$ of remittances on education and investment respectively (IFAD, 2017).

Remittances consider as a major source of finance in developed and developing countries. According to the recent data from Migration Development Brief in 2017, worldwide the flows of remittance were estimated to be $\$ 575$ billion, with about $\$ 429$ billion flowing to developing countries in 2016. The size of remittance inflow to developing countries is much higher than their foreign direct investment. It reached three times the official development assistance (ODA) (Stanley \& Buckley, 2016). In addition, the top 10 countries that possess the greatest remittances, as a share of GDP, are all developing countries, as shown in graph 1.5. Kyrgyz Republic recorded that $34.5 \%$ of their GDP depends on remittances, whilst the lowest is Honduras in which $18.4 \%$ 
of their GDP is contributed by remittance. This places remittances as the main concern for policymakers due to its sheer volume.

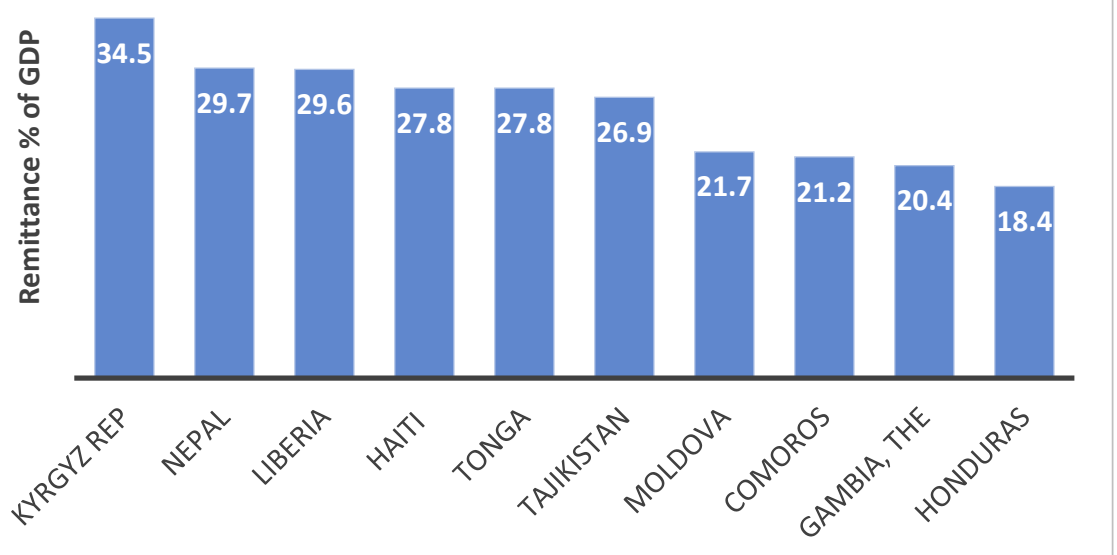

Figure 1. Top 10 remittance-receiving countries (\% of GDP)

(Source: Migration and Development Brief (2017)).

Remittance-growth nexus has attracted much literature, and the findings are mixed and still inconclusive. Several studies found that remittance enhances economic growth (Meyer \& Shera, 2017), however, others found that remittance deteriorates economic growth of the host countries (Chami et al., 2005), or having no such effect (Rao \& Hassan, 2011; Barajas et al., 2009). While other studies have found a conditional effect between remittance and growth via institutional quality and financial development (Singh et al., 2011; Catrinescu et al., 2009).

For the positive effect, a study Meyer \& Shera (2017) used a fixed-effect model on six high remittances receiving countries namely; Albania, Bulgaria, Macedonia, Moldova, Romania, and Bosnia Herzegovina during the years of 1999-2013. Remittance inflow in the six countries represents more than $10 \%$ of GDP. Their findings suggest that remittance positively and significantly impacts GDP per capita and that this impact increases at a higher level of remittance relative to GDP.

On the other hand, other past studies found remittance-economic growth link is negative. For instance, a study on 113 developing and developed countries using the fixed-effect method, Chami et al. (2005) find that the growth effects of remittances are negative. They concluded that remittances allow recipients to decrease their own work in which remittance substitute work income. This is then translated into a reduction in the labor supply and labor market participation. The latter study argued that remittance cannot be one of the capital flows due to its behavior and its nature as a compensatory income. Whilst, a study of Barajas et al. (2009) on 101 developing countries examines the effects of remittances on growth during the period 19702003, found no significant relationship between remittance and economic growth, or between remittance and other control variables, such as investment rates and education. The key behind this is that remittances generally serve as social insurance to help family members finance their life's necessities instead of investments. Similarly, the study of Adams \& Klobodu (2016) claims that remittance affects growth only in the presence of sound institutional quality such as democracy and stable government. In addition, Rao \& Hassan (2011), using two indicators of 
remittance; 1 ) remittances by all non-residents and 2) remittances only by non-residents who are classified as residents in a foreign country and taxed there. They found no significant relationship between remittance and growth.

Growth effects of remittances have been argued to be conditional. For instance, Singh et al (2011) analyzed data for 36 African countries for a period of 1990-2008 using a fixed-effect estimate. They found that remittance has a negative impact on growth in case of direct effect. Whereas, countries with sound domestic institutions help to channel remittances to contribute to foster economic growth. Catrinescu et al. (2009) used a wide range of institutional quality indicators (ICRG Composite Political Risk Indicator and six governance research indicators). They argued that sound institutional quality has been found to affect the volume and efficiency of investment; e.g. in the presence of good institutions, remittance could be invested efficiently and in a greater amount, this ultimately leads to higher economic growth. In addition, Ngoma and Ismail (2013) found that an increase in average in remittance by $1 \%$ leads to a $2 \%$ increase in years of schooling at both secondary and tertiary levels. This indicates that remittance potentially relaxes liquidity constraints and facilitates more schooling opportunities in remittance-receiving countries.

The main motivation of this study is the inconclusive results emerged from previous studies on remittance-growth nexus. Literature is divided into whether remittance is a blessing or a curse to economic growth. Therefore, this study contributes to previous studies using numerous low and middle-income countries to further examine remittance-growth nexus. Therefore, this study will be significant to both scholars and policymakers. First, this study will be significant to graduates and researchers as it provides a discussion on the issue of curse or blessing effect of remittances. For policymakers, it helps to design national policies that enable the flow of remittance with higher growth attainment. The remainder of this article is organized as follows: Section 2 outlines the materials and methods used in the study. Where section 3 illustrates the findings and gives discussions of the augmented results. Last, section 4 concludes and provides policy recommendations.

\section{Materials and Methods}

The aim of this paper is to examine the effect of remittances on economic growth in 93 low and middle-income countries. Thus, the empirical model augmented the work of Singh et al. (2011) and the model is as follows:

$$
\begin{gathered}
\ln G D P C_{i t}=\alpha+\beta_{1} \ln G D P C_{i, t-1}+\beta_{2} \ln R E M_{i t}+\beta_{3} \ln H C_{i t}+\beta_{4} P O P_{i t}+\beta_{5} \ln G O E+ \\
\beta_{6} \ln I N V_{i t}+v_{i}+\eta_{t}(1)
\end{gathered}
$$

Where the subscripts $i$ and $t$ are the country and time index, respectively, the dependent variable used is GDP per capita is gross domestic product divided by midyear population (constant 2010 US\$). Remittances are personal remittances received and are defined as the percentage of GDP, where $(\mathrm{HC})$ is a human capital's proxy is life expectancy at birth, total (years), government expenditure (GOE) is the general government final consumption expenditure (\% of GDP), investment is Gross fixed capital formation (\% of GDP), and population growth. $v_{i}$ is a country-specific effect, $\eta_{t}$ is the time-specific effect, and $u_{i t}$ is the error term. It worth noting that the control variables included in the model are based on Cobb-Douglas production function with a shared parameter of physical capital (investment) and human capital, and these variables are assumed to be positively correlated with growth. Where the population is used by Acemoglu 
\& Johnson (2005), and the government expenditure is used by Acemoglu et al. (2008). The data for these variables are derived from the World Development Indicators (WDI) published by the World Bank.

The general method of moments (GMM) proposed by Holtz-Eakin et al. (1988) and extended by Arellano and Bond (1991), Arellano and Bover (1995), and Blundell and Bond (1998). The estimation is carried out using the System GMM (SYS-GMM) estimator on a panel of 93 emerging economies over the period 2009-2017. In addition, diagnostic tests are applied to confirm the reliability of augmented results, hence two diagnostic tests are used based on Arrelano and Bond (1991) to assess first (AR1) and second-order serial correlation (AR2) in the errors. The rule of thumb suggests that first-order serial correlation could be rejected, but it cannot be rejected for the second order. The second test is Hansen (1982) J test of overidentifying restrictions to test the issue of over-identification, which caused by many instruments that would lead to bias estimation.

We use the system GMM estimator because it is consistent in parameters and unbiased compared with pooled ordinary least squares (OLS), fixed effects, and random effects. The system GMM is able to control for endogeneity problem by using the lagged values of the levels of the endogenous and the predetermined variables as instruments. Blundell \& Bond (1998) showed that the SGMM estimator performs better than the difference GMM due to the instruments in the levels equation are good predictors for the endogenous variables in this model even when the series is very persistent. Hence, it is argued that the SGMM estimator allows to use more instruments due to lagged explanatory variables of the level and first difference model, and many instruments problem could be serious.

\section{Results and Discussion}

Table 1 and 2 below provide descriptive statistics and the correlation between the variables under this study. A significant variation is observed in GDP growth income across the sampled countries. It ranges from as low as \$214.13 in Burundi to as high as \$21399.1 in Cambodia. This wide disparity could be due to domestic and external factors, such as remittances and others. Similarly, remittances show considerable variations, from a minimum of $0 \%$ for Gabon and a maximum of $43.47 \%$ for Tajikistan. Table 2 indicates the correlation between the dependent variable and the main independent variable namely remittance is negative and the value showing not very high correlation which is at 0.163 . The highest correlation value is between the population and GDP at 0.839 .

Table 1: Descriptive Statistics

\begin{tabular}{|c|c|c|c|c|c|}
\hline $\begin{array}{l}\text { Variabl } \\
\text { e }\end{array}$ & Obs & Mean & Std.Dev. & Min & Max \\
\hline GDPC & 837 & 4957.036 & 4653.511 & 214.1393 & 21399.1 \\
\hline REM & 834 & 5.794 & 7.139 & 0 & 43.469 \\
\hline GOE & 813 & 15.288 & 4.966 & 5.039 & 38.434 \\
\hline POP & 837 & $5.72 e+07$ & $1.93 e+08$ & 618000 & $1.39 e+09$ \\
\hline INV & 824 & 24.119 & 7.751 & 5.885 & 74.608 \\
\hline $\mathrm{HC}$ & 744 & 81.856 & 32.909 & 20.723 & 185.747 \\
\hline
\end{tabular}


Table 2: Matrix of correlations

\begin{tabular}{lrrrrrr}
\hline $\begin{array}{l}\text { Variable } \\
\mathrm{s}\end{array}$ & GDPC & REM & GOE & POP & INV & HC \\
\hline GDPC & 1 & & & & & \\
REM & - & 1 & & & & \\
& 0.163 & & & & & \\
GOE & - & 0.046 & 1 & & & \\
& 0.054 & & & & & \\
POP & 0.839 & -0.119 & -0.159 & 1 & 1 \\
INV & 0.260 & -0.167 & 0.027 & 0.268 & 0.080 & 1 \\
HC & - & 0.104 & 0.263 & -0.243 & & \\
& 0.222 & & & & & \\
\hline
\end{tabular}

The results of remittance impacts on growth are discussed in Table 3 below in model (1) and (2). The results show no significant impact of remittance on growth for the two models similar to the results of previous literature (Rao \& Hassan, 2009; Barajas et al., 2009). (; Rao \& Hassan, 2011). Meanwhile, the sign of remittance is negative for the two models, which indicates that remittance diminishes growth in the receiving countries. This supports the curse view of the "Dutch disease" of remittance affecting growth (Chami et al., 2005). The results confirm that remittance is different than other capital flow such us FDI (Chami et al., 2005). The reason behind this is that remittance functions as compensation to remittance recipients and contribute to their income, which is channeled to consumption but not to investments. The results of the controlling variables are consistent with the theory. For instance, human capital and investment are significant and positively impact growth, and also population growth is negative and significantly impacts growth in low and middle-income countries.

The results of the model (1) and (2) determined that there exists a negative relationship between remittance and economic growth, however the non-significance maybe due to outliers that blur the true relationship. Therefore, a robustness check is recommended to remove the outliers in the data so that a true relationship may have different results. Additionally, another proxy for the dependent variable is applied, namely GDP growth instead of GDP per capita. The augmented results are presented in the model (3) and (4) in the table below. 
INTERNATIONAL JOURNAL OF ACADEMIC RESEARCH ECONOMICS AND MANAGEMENT SCIENCES

Vol. 9, No. 2, 2020, E-ISSN: 2226-3624 @ 2020 HRMARS

Table 3: The effect of remittance on economic growth.

\begin{tabular}{|c|c|c|c|c|}
\hline Variables & (1) & (2) & $\begin{array}{c}\text { (3) } \\
\text { Robust check }\end{array}$ & $\begin{array}{c}\text { (4) } \\
\text { Robust check }\end{array}$ \\
\hline Constant & $\begin{array}{c}-0.1029 \\
(0.0721)\end{array}$ & $\begin{array}{l}-0.0873 \\
(0.0819)\end{array}$ & $\begin{array}{c}-0.0203 \\
(0.1065)\end{array}$ & $\begin{array}{c}0.8227^{* * *} \\
(0.2625)\end{array}$ \\
\hline $\ln G D P C_{i, t-1}$ & $\begin{array}{c}0.9854^{* * *} \\
(0.0067)\end{array}$ & $\begin{array}{c}0.9761^{* * *} \\
(0.0062)\end{array}$ & $\begin{array}{c}0.9693 * * * \\
(0.0093)\end{array}$ & $\begin{array}{c}0.9559 * * * \\
(0.0093)\end{array}$ \\
\hline InREM & $\begin{array}{c}-0.0058 \\
(0.0041)\end{array}$ & $\begin{array}{l}-0.0051 \\
(0.0037)\end{array}$ & $\begin{array}{c}-0.0086 * * \\
(0.0039)\end{array}$ & $\begin{array}{l}-0.0060 \\
(0.0051)\end{array}$ \\
\hline $\mathrm{InHC}$ & $\begin{array}{c}0.0587^{* * *} \\
(0.0108)\end{array}$ & $\begin{array}{c}0.0564^{* * *} \\
(0.0115)\end{array}$ & $\begin{array}{c}0.0501 * * * \\
(0.0127)\end{array}$ & $\begin{array}{c}0.0411 * * \\
(0.0201)\end{array}$ \\
\hline InINV & $\begin{array}{c}0.0354^{* * *} \\
(0.0092)\end{array}$ & $\begin{array}{c}0.0301 * * * \\
(0.0077)\end{array}$ & $\begin{array}{c}0.0392 * * * \\
(0.0093)\end{array}$ & $\begin{array}{c}0.0324 * * \\
(0.0126)\end{array}$ \\
\hline POP & $\begin{array}{c}-0.0205 * * * \\
(0.0033)\end{array}$ & $\begin{array}{c}-0.0210 * * * \\
(0.0041)\end{array}$ & $\begin{array}{c}-0.0239 * * * \\
(0.0068)\end{array}$ & $\begin{array}{c}0.0000 * * \\
(0.0000)\end{array}$ \\
\hline InGOE & $\begin{array}{c}-0.0319 * * \\
(0.0128)\end{array}$ & & & \\
\hline$A R(2)$ ( $p$-value) & 0.288 & 0.308 & 0.457 & 0.289 \\
\hline J- test ( $p$-value) & 0.420 & 0.406 & 0.649 & 0.138 \\
\hline No. of instruments & 36 & 35 & 35 & 17 \\
\hline Country & 93 & 93 & 91 & 93 \\
\hline No. of Observation & 643 & 646 & 601 & 647 \\
\hline Time dummies & Yes & Yes & Yes & No \\
\hline
\end{tabular}

Note: ${ }^{* * *} \mathrm{p}<0.01,{ }^{* *} \mathrm{p}<0.05, * \mathrm{p}<0.1$; and Standard errors are in parenthesis

\section{Robust Check}

The robust check we applied is to detect and remove outliers, therefore, Cook's Distance Outlier test is applied (Law et al., 2018). Model (3) in the table above shows the remittancegrowth link after removing outliers. Results show that the sign of remittance kept intact while the relationship turns to be significant. This indicates that outliers blur the true relationship before in model (1) and (2), and there is a negative and significant link between remittance and economic growth in low and middle-income countries. In addition, the coefficient of remittance is slightly changed after outliers. The results confirmed the previous study of Chami et al. (2005) that remittance considers as compensatory transfer and does not spur growth in the receiving countries. 


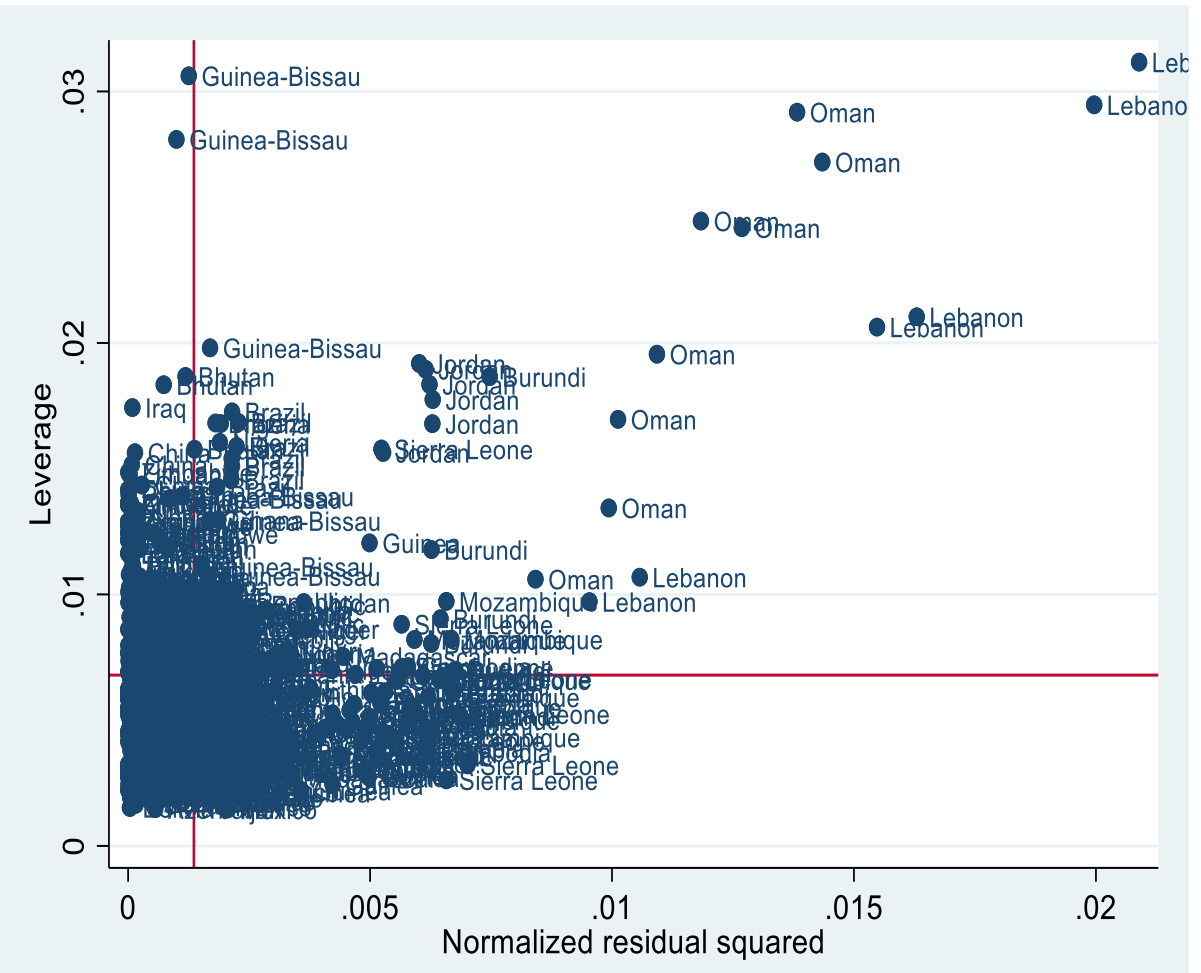

Graph 2: Scatter plot of leverage vs residual squared for remittance-growth equation.

The graph above shows the scatter plot of the countries, and we can see that Lebanon has some observations that are considered as outliers, also Oman and Guinea-Bissau. After these outliers are removed the results are presented in Table 1 above in model (3). Most importantly, remittance impacts on growth turn to be significant and supporting the curse effect. The argument is that more remittance flow to the countries, the lower growth due to the nature of remittance as it is considered as nontaxable income. Also, argued that remittance recipients are not willing to demand jobs due to the money receiving from the diaspora, thus less production that leads to lower growth. This view classifies remittance as a resource curse similar to natural resource-abundant as such oil. Model (3) indicates, one percent increase in remittance would have a negative impact on growth per capita income by $0.008 \%$. The rest of the control variables are consistent and have correct expected signs on their growth impacts (. Model (4) is a second robustness check using GDP constant instead of GDP per capita. The results are similar to the previous augmented results, however, the impact of remittance is insignificant as same as the results of models (1) and (2). The mixed results of remittance are maybe due to the panel data analysis that probes different countries, and also it may be attributed to the long-run and shortrun effect, which remittance is claimed to have a short run effect on growth but not in the long run (Paul \& Das, 2011).

\section{Conclusion}

This study examines the relationship between remittance and economic growth in 93 low and middle-income countries. In other words, this study presents a relative question; does remittance has a curse or bless impact on growth? Using data of 93 low and middle-income 
countries over the period of 2009 to 2017, we use the SYS-GMM estimator to examine the mentioned relationship. The results confirm existing of a negative relationship between remittance and growth in the countries under study. However, the relationship turns out to be significant only after removing outliers. This confirms that the bigger size of remittance flow tends to harm growth. Therefore, the findings support the curse view "Dutch disease" that caused by remittance towards growth. Therefore, policymakers should be more caution in dealing with remittance especially it is categorized under capital flow type, which may have unpleasant consequences.

\section{References}

Acemoglu, D., Johnson, S., Querubin, P., \& Robinson, J. A. (2008). When does policy reform work? The case of central bank independence (No. w14033). National Bureau of Economic Research.

Acemoglu, D., \& Johnson, S. (2005). Unbundling institutions. Journal of political Economy, 113(5), 949-995.

Adams, S., \& Klobodu, E. K. M. (2016). Remittances, regime durability and economic growth in Sub-Saharan Africa (SSA). Economic Analysis and Policy, 50, 1-8.

Adams Jr, R. H., \& Page, J. (2005). Do international migration and remittances reduce poverty in developing countries? World development, 33(10), 1645-1669.

Arellano, M., \& Bond, S. (1991). Some tests of specification for panel data: Monte Carlo evidence and an application to employment equations. The review of economic studies, 58(2), 277297.

Arellano, M., \& Bover, O. (1995). Another look at the instrumental variable estimation of errorcomponents models. Journal of econometrics, 68(1), 29-51.

Barajas, A., Gapen, M. T., Chami, R., Montiel, P., \& Fullenkamp, C. (2009). Do workers' remittances promote economic growth? (No. 2009-2153). International Monetary Fund.

Blundell, R., \& Bond, S. (1998). Initial conditions and moment restrictions in dynamic panel data models. Journal of econometrics, 87(1), 115-143.

Catrinescu, N., Leon-Ledesma, M., Piracha, M., \& Quillin, B. (2009). Remittances, institutions, and economic growth. World Development, 37(1), 81-92.

Chami, R., Fullenkamp, C., \& Jahjah, S. (2005). Are immigrant remittance flows a source of capital for development?. IMF Staff papers, 52(1), 55-81.

Edwards, A. C., \& Ureta, M. (2003). International migration, remittances, and schooling: evidence from El Salvador. Journal of development economics, 72(2), 429-461.

Fajnzylber, P., \& Lopez, J. H. (2008). The development impact of remittances in Latin America. Remittances and Development, 1.

Giuliano, P., \& Ruiz-Arranz, M. (2005). Remittances, financial development and growth IMF Working paper 05/234. International Monetary Fund, Washington DC, USA.

Hansen, L. P. (1982). Large sample properties of generalized method of moments estimators. Econometrica: Journal of the Econometric Society, 1029-1054.

Holtz-Eakin, D., Newey, W., Rosen, H. (1988). Estimating vector autoregressions with panel data. Econometrica 56, 1371-1395.

Law, S. H., Kutan, A. M., \& Naseem, N. A. M. (2018). The role of institutions in finance curse: Evidence from international data. Journal of Comparative Economics, 46(1), 174-191. 
Meyer, D., \& Shera, A. (2017). The impact of remittances on economic growth: An econometric model. EconomiA, 18(2), 147-155.

Ngoma, A. L., \& Ismail, W. (2013). Do migrant remittances promote human capital formation? Evidence from 89 developing countries. Migration and Development, 2, 106-116.

Paul, B. P., \& Das, A. (2011). The Remittance-GDP Relationship in the Liberalized Regime of Bangladesh: Cointegration and Innovation Accounting. Theoretical \& Applied Economics, 18(9).

Rao, B. B., \& Hassan, G. M. (2011). A panel data analysis of the growth effects of remittances. Economic modelling, 28(1-2), 701-709.

Singh, R. J., Haacker, M., Lee, K. W., \& Le Goff, M. (2011). Determinants and macroeconomic impact of remittances in Sub-Saharan Africa. Journal of African Economies, 20(2), 312-340.

Stanley, R. L., \& Buckley, R. P. (2016). Protecting the west, excluding the rest: The impact of the $A M L / C T F$ regime on financial inclusion in the pacific and potential responses. Melb. J. Int'l L., 17, 83.

\section{APPENDIX}

Table2: Sources and measurements of variables

\begin{tabular}{|c|c|c|}
\hline Variables & Measurement & Data source \\
\hline Remittance (REM) & $\begin{array}{l}\text { Personal } \\
\text { remittance as a } \\
\text { percentage of } \\
\text { GDP }\end{array}$ & $\begin{array}{l}\text { World Development } \\
\text { Indicators }\end{array}$ \\
\hline GDP per capita (GDPC) & $\begin{array}{l}\text { GDP per capita } \\
\text { (constant } 2010 \\
\text { US\$) }\end{array}$ & $\begin{array}{l}\text { World Bank national } \\
\text { accounts data, and } \\
\text { OECD National } \\
\text { Accounts data files. }\end{array}$ \\
\hline Human Capital (HC) & $\begin{array}{l}\text { Life expectancy at } \\
\text { birth, total (years) }\end{array}$ & $\begin{array}{l}\text { World Development } \\
\text { Indicators }\end{array}$ \\
\hline Population (POP) & $\begin{array}{l}\text { Population } \\
\text { density }\end{array}$ & $\begin{array}{l}\text { World Development } \\
\text { Indicators }\end{array}$ \\
\hline Investment (INV) & $\begin{array}{l}\text { Gross capital } \\
\text { formation as a } \\
\text { percentage of } \\
\text { GDP }\end{array}$ & $\begin{array}{l}\text { World Development } \\
\text { Indicators }\end{array}$ \\
\hline $\begin{array}{l}\text { Government Expenditure } \\
\text { (GOE) }\end{array}$ & $\begin{array}{l}\text { General } \\
\text { government final } \\
\text { consumption } \\
\text { expenditure (\% of } \\
\text { GDP) }\end{array}$ & $\begin{array}{l}\text { World Development } \\
\text { Indicators }\end{array}$ \\
\hline
\end{tabular}

